\title{
A theoretical review on the structural convergence issue and the relation to economic development in integration areas
}

\author{
Alina Petronela ALEXOAEI \\ The Bucharest University of Economic Studies, Bucharest, Romania \\ alina.alexoaei@yahoo.com \\ Raluca Georgiana ROBU \\ The Bucharest University of Economic Studies Bucharest, Romania \\ ralucageorgianarobu@gmail.com
}

\begin{abstract}
The aim of the paper is to provide a consistent literature review on the importance of structural convergence for the countries within the same economic area focusing on two main topics: the structural similarity problem of countries within an integration area and the evolution and development of the union itself (in line with Chenery and Singer's approach). We aim to synthesize the most referential findings of the literature and project them on the most recent events in the European Union pointing out the relevance of structural convergence and of the continuation of the process under a reassessed form. The relevance of studying the structural convergence process lies in the medium and long term implications related to the synchronization of business cycles, long-run development patterns and of the dynamics of specialization. Moreover, the topic is of high interest both in the context of the future evolution of the European Union and in the decision making process of adopting the Euro in Romania's case. On the side of theoretical papers, there is a rich literature on structural change that generally recommends that economic structures and the differences between them should be the starting point for analysis and development of theories of economic development. We believe that the preoccupations for this topic should be recalled in the context of the European events and new facets should be explored. Along with the views expressed in the European Commission White Paper, that the form will follow the function, we emphasize the importance of designing the proper institutions at European Union and Eurozone level, but also at national level with taking into consideration the goal of advancing towards structural convergence.
\end{abstract}

Keywords: structural convergence, similarity, European integration, integration area.

\section{Introduction}

The concern for the convergence process and the analysis of pair of countries is not a recent one, but scholars' attention was initially directed towards investigating nominal convergence between the European Union (EU) member countries, followed by studies on the real convergence criteria and lately on the concept of structural convergence (Chilian et al., 2016). Empirical studies regarding the EU member countries (mainly conducted for the period of 1990-2007) show that in terms of real convergence, countries within the Euro area converge in several key aspects such as productivity, labour market indicators, income per capita, however in terms of economic structures convergence things are not that clear and easy to track (Marelli et al., 2012; Scharpf, 2016), the phenomenon itself having a limited understanding (Knill, 2007). The worry is that countries outside the Eurozone and those that want to accede it, diverge even more and still do not meet the nominal convergence criteria: inflation rate and price stability, sound governmental finances and 
fiscal stabilization, long-term interest rates and exchange rate stability (European Commission, 2016).

As for analysis on Romania's case, real and structural convergence at county level during the pre- and post-accession periods, although as relevant in the process of convergence and catching up, has been subject of even fewer studies (ex: Palan and Schmiedeberg, 2010; Paci and Pigliaru, 1997; Longhi and Musolesi, 2007; Dima and Vasilache, 2016).

Structural convergence is defined in several ways, according to different indicators used to measure the phenomenon, but it is basically the convergence in sectoral structures which is added to the convergence in the per capita income (Wacziarg, 2004). The relevance of studying the process of structural convergence resides in the "medium and long term implications related to the synchronization of business cycles (if the shocks are sectoral) and on the dynamics of specialization and economic development model" (Wacziarg, 2001, p.1). The European Economic Advisory Group (EEAG, 2011) points out the key role of structural similarity within a monetary union and emphasizes the risk of economic and financial divergence as a consequence of not meeting it. Structural convergence can be attained once the following three processes are completed: the degree of similarity of economic structures, synchronization of business cycles, and trade integration (foreign trade). Hence, a high structural similarity level can be considered one of the key elements of the structural convergence process because it can mitigate eventual shocks caused by a lack of business cycle synchronization or by dissimilarities in the shock transmission mechanism. The empirical literature proves a positive impact of structural similarity on business cycle synchronization (Beck, 2014).

The purpose of the paper is to review both theoretical and empirical literature about the importance of structural convergence for the countries within the same economic area with a great emphasis on the structural similarity problem and the implications on the synchronization of business cycles, on specialization and on economic development.

We begin by synthesizing the most eloquent studies that define structural convergence and the related concepts, simultaneously looking at the focus in the empirical literature related to structural convergence, and we continue by explaining the intricate links between structural convergence and economic growth and particularize on the European Union. We conclude with the most referential findings of the literature and project them on the most recent events in the European Union pointing out the relevance of structural convergence and of the continuation of the process under a reassessed form.

\section{Literature review}

\section{Defining structural convergence and related concepts}

In the European context, structural similarity, as one of the elements that compose structural convergence, can provide information on the extent to which countries have the potential to form an optimal currency area, as well as on the level of integration within the Single Market and on the (dis)similar specialisation between them. Nevertheless, even if two countries register a high export structure similarity and a high level of business cycle synchronization, if structural differences still exist, there are good premises for them to diverge on the long run since non symmetrical economic structures will translate in 
different responses to common shocks and even more, the probability of asymmetrical shock to arise becomes higher.

The concept of structural convergence refers to the process leading to similarity in terms of economic structure associated with a convergence of income per capita, a process important for countries belonging to the same economic area and especially for members of a monetary union. Economic alignment of Euro area countries, although unregulated, is one of the fundamental prerequisites for the good functioning of the monetary union.

The term "economic structure" has no generally accepted definition and it compounds a wide variety of characteristics of an economy. In most cases it refers to the composition and evolution of components of an economy such as consumption, production, trade, employment and government spending. Branson et al. (1998) identify the sectoral shares of labour force, consumption patterns and income distribution as the most traditional particularities that define an economic structure, to which Kuznets (1956) added the variables related to sectoral shares of GDP together with a set of trade-related variables. Chenery and Syrquin (1975) also include variables such as: education, demographic transition, government revenues, investment and urbanization. Related to economic structures are structural changes.

The concept of structural change is used to identify, interpret and understand the causal relationship between economic development and changes in the size and composition of economic sectors. Structural economic changes can be defined as temporal changes of the macroeconomic objectives and of the co-dependencies between them corresponding to circular income flows (Jackson et al., 1989). Kuznets in "Economic Development and Cultural Change (various issues)" added the analysis of sectoral contribution to GDP and some trade-related variables.

The definition of these concepts differ from one author to another and included different sets of variables because they were adapted to the purpose of finding specific correlations among the convergence of certain economies and economic development, the capacity to adjust to economic shocks or the capacity to form an optimum currency area. The exemplification of empirical studies that were conducted in this field depicts the variety of scope for the concept of structural convergence and is contained in the next section of the paper.

\section{The focus in the empirical literature related to structural convergence}

Studies on the economic alignment of countries have had different focus areas and levels: structural convergence at an industrial level (Höhenberger and Schmiedeberg, 2008), the role of agriculture in the process of structural convergence (Sassi, 2007; Fertő, 2016), the transition from an agriculture based economy to an industrial and then service one (Chong et al., 2017), regional convergence (Cuadrado-Roura et al., 1999; Guerrieri and Iammarino, 2003; Longhi and Musolesi, 2007; Crespo and Fontoura, 2009; Di Berardino et al., 2017) the relationship between income and structural convergence (Imbs and Wacziarg, 2003), convergence in the field productivity (Fagerberg, 2000; Gugler and Pfaffermayr, 2004) and the causal link convergence - monetary union integration (Brülhart, 1998). Other authors have analyzed economic catching-up process between groups of industrialized countries, newly industrialized and less industrialized (Abegaz, 2002) or of countries from Central 
and Eastern Europe (Landesmann, 2000) and, more recently, on the new EU member states Euro adoption (Miron et al. 2009, Brixiova et al., 2009 and Juncker et al., 2015), or a reassessment of the convergence achievements of countries which already are members of the Eurozone (Palan and Schmiedeberg, 2010).

Having in mind the causal link between structural changes and economic development, there is a rich literature on structural change, including the important contributions of Kuznets (1966), Kaldi (1961), and Chenery (1979) with a revival of the interest in this theme in more recent writings (Acemoglou and Guerrieri 2008, Buera and Kaboski 2008, Matsuyama 2008, Ngai and Pissarides 2007). While recent literature has broadened and deepened the scope of the investigation, emphasis was put on explaining the key stylized facts of structural change. These facts include: positive correlation between international prices of unsold services and per capita income, positive association between income per capita and labor productivity relative to the commercial sector, positive correlation between per capita income, rental and wage report, a positive association between share (nominal) of services in consumer spending and income per capita (Srinivasan and Quibria, 2009).

\section{Structural convergence and economic development Factors and implications}

Structural convergence is an aspiration of less developed economies which want to converge to more developed ones. For developed economies it is also in their advantage to cooperate with countries which structurally converge because this means similar consumer behavior, similar purchase power, bigger and similar markets, cross-border movement of resources, similar investment behavior, similar education level, technological level, etc. If structural convergence is attained, all the converging economies will eventually be able to cooperate more, economically and politically, coordinate their policies and speak with a common voice in relation to third parties.

Structural convergence can be analyzed from two perspectives: inter-sectoral convergence and inter-branch convergence. Fourastié (1949) can be considered as the first author who studied inter-sectoral convergence, within the theory known as the "assumption of the three sectors": extraction of raw materials (primary), manufacturing (secondary) and services (tertiary). The theory predicts that an economy as it grows, will change the sector it specializes in. In the stage of a low national income country, economic activity and specialization will rely on the production and export of raw materials, , while in the stage of the highest level of development, that country is very likely to become a service-based economy. The speed of transition dependents on three main factors: (1) initial deviation from the model development structure model, (2) GDP growth rate, and (3) trade policy followed. All three combined have produced a very rapid transformation of the economy of South Korea (Chenery, 1982). The three sectors hypothesis predicts that countries with similar levels of development will be characterized by similar inter-sectoral structure but of course, structural convergence level will never be absolute due to differences in size, resource endowments, culture or institutional characteristics (Chenery, 1960). 
The evolution from underdeveloped to developed economy can be defined by a set of structural changes that may vary depending on the endowments and social characteristics of each country, but there are still many factors that lead to a certain level of uniformity in the transition process: similar changes in consumer demand, an increase in income levels, the need and tendency to accumulate physical and human capital and improved access to sources of technology and trade (Chenery, 1982).

PICBE | 38

Further on, we particularize on structural similarity, as a key element of the process of structural convergence, and its relation to economic growth. We believe that this matter deserves a special attention because, if business cycles are unsynchronized in the case of asymmetric shocks or differences in the mechanisms of transmission of common shocks, structural similarity can smooth the impact on the economies of the synchronized countries.

Studies on the structural similarity begin with listing the factors that influence, determine and explain the similarity. Analyses include national income among the variables that determine the structural similarity, so that countries converging in terms of income per capita tend to converge in terms of sectoral similarity and of sectoral labor productivity (Wacziarg, 2004). Convergence of determinants of comparative advantage in the HeckscherOhlin model (such as relative abundance of labor) can also lead to structural similarity and countries and including regions will tend to produce similar product categories. Barrios et al. (2002) suggests that the relative size of regions is a factor influencing the degree of economic similarity, assuming that the ratio of similarity decreases the difference in terms of territorial size of the regions analyzed.

Generally, the results of empirical studies have confirmed the above factors' influence on the process of similarity that may occur between countries / groups of countries. In a study based on 14 European countries, Barrios et al. (2002) demonstrate the importance of similarity in income per capita regarding the economic structures tendency to align. Wacziarg (2004) confirms the conclusion of Barrios et al. (2002) regarding the association of similarity in terms of income per capita and the structural similarity, but he also tests the influence of resource endowment similarity (land, capital and labor). The results demonstrate the relationship of interdependence between income per capita and capital, but found no correlation with related land resources and labor. Gravitational factors as geographical proximity and the existence of common borders and relative size of the population were also taken into account as potential determinants of structural similarity, and they are showing a significant positive influence on the structural similarity of economic areas analyzed (Crespo and Fontoura, 2009).

\section{Structural convergence in the European Union}

Due to the existence of common institutions, policies, regulations and to some extent resources, the European Union provides a suitable framework for empirical analysis and testing of the pattern of growth and structural change. The premises to see if a common pattern of development exists between the member countries rely on the existing growth and development models associate structural change with the variations in GDP per capita and population. At the same time, we can see if latecomers register a different pattern in terms of resource allocation and accumulation, and demographic evolution. Empirical 
results tend to confirm the different nature of development for countries that have had a late start (Prados de la Escosura, 2007).

The level of similarity is measured by different methods leading to results which are hard to compare. Cincibuch \& Vavra (2000) estimated the economic similarity of the Czech Republic to the euro area using the proposed determinants of optimum currency area (OCA): destination of foreign trade, composition of goods exports and the correlation of business cycles. They find a good convergence among Eurozone countries in Western Europe and a weak convergence among CEE countries before 2013. But authors in empirical literature do not generally agree on the foundations relevance of the OCA theory and its application in the Eurozone governance (Snaith, 2014; Qiu, 2014).

Stronger trade links can promote thus a higher correlation/similarity of economic activity in a single monetary zone (Frankel and Rose, 1997). On the other hand, a high trade intensity may lead to increased specialization and, consequently to lower levels of structural similarities (Krugman, 1993). Mongelli et al. (2016) recall the problem of the optimum resource allocation, which fails in case of bad specialization, showing that frictions actually help the process of directing resources towards more productive companies.

While the matter is still under debate, "it was expected that the adoption of a single currency would give strong incentives to carry out structural reforms to compensate for the loss of monetary policy as a stabilization tool" (Buti and Turrini, 2015).

The empirical literature proves that the convergence level differs according to the economic level where the analysis is taken. The promoter of structural convergence is intersectoral structural change because the ratio of the three aggregate sectors is becoming more similar over time due to processes of industrialization and transition to the tertiary sector (Höhenberger and Schmiedeberg, 2008). Intra-sectoral convergence, however, cannot be traced: in either manufacturing or services, European countries do not seem to converge, being rather divergent. This is not surprising because the aggregate industries in these sectors cannot develop in similar directions. Some industries may diverge because of data dependencies of model development and economies of scale, while in other industries congestion costs and high labor costs of production sites can lead to convergence. As these trends (simultaneously) can cancel each other when they are analyzed as an aggregate, an industry level analysis is required to detect trends of convergence / divergence intrasectorial.

A particular interesting topic can be developed on the question of how much to converge in the European Union is the higher education system. It is desirable to have a certain differentiation that corresponds to students, resources and labor market particularities. In the same time convergence regarding the formal structure of universities improves mobility and the recognition of certificates among member states (Dunkel, 2009). Teichler (2012) evaluated the results of the Bologna process regarding the improvement of mobility and he showed that students from outside the EU increased their mobility but between students from member states there are still notable differences. Generally convergence in higher education is an ongoing process, but differences persist because of the initial large gaps and the lower speed of some countries or in some areas (Dima, 2014). Among the causes Dima (2014, pp. XXII) mentions: "excessive control, defective governance, lack of appropriate funding". The current priorities in the Bologna process 
reveal the fact that convergence in higher education should focus on the quality improvement of educational services, improving the employability of graduates, inclusive systems and implementing structural reforms (European Commission, 2015).

\section{Conclusion}

Structural convergence is a complex concept and phenomenon. As a consequence, its definitions are not very strict, nor precise and refer to a wide range of conditions that must be attained by structurally converging economies and still remain open to be completed.

Structural converge has not been attained in an absolute form anywhere in the world and nor it is possible to do so. But, because it is considered to have a positive relation to economic growth, countries that succeed to do more in converging their economic structures, can hope for a consolidation of their strategic position, more opportunities for future development and to avoid asymmetric shocks. These characteristics have led to two tendencies in the literature:

(1) Although a relatively recent concept, since it was introduced there have been hard efforts to theorize it, to increase awareness about it and to empirically prove its wide implications and its causal factors. Numerous policies were proposed and the assessment of the convergence success in different examples was carried out.

(2) The empirical literature has focused more on nominal convergence as compared to structural or real convergence, because it is easier to measure, the conditions are precise, and for the case of the European Union, only nominal convergence criteria is imposed. However, many authors agree that especially for the European Monetary Union adhesion structural convergence and real convergence are very important.

The literature generally recommends that economic structures and the differences between them should be the starting point for analysis and development of theories of economic development. The fundamental premise is that countries that are in different stages of development tend to have different economic structures due to the differences that exist between them in terms of resource endowments.

After synthesizing the meaning and implications of the structural convergence issue, we believe that the preoccupations for this topic should be recalled in the context of the European events.

The five scenarios sketched by Jean-Claude Juncker in the White Paper on the future of Europe in March 2017 refer to how many and how profound would be the choices made in common (European Commission, 2017). While previously there were many discussions about the adequate institutions that would drive the EU to further integration (at national, subnational or EU level), the phrasing of the five scenarios does not mention at all the design of the institutions and institutional processes because the "form will follow the function". Although the convergence issue is hardly even mentioned, and the scope is much wider than economic aspects, it becomes visible that even the most basic form of cooperation, such as in scenario 2: "nothing but a single market", cannot be absolute without the harmonization of legislation. And this harmonization, in our view, would hardly produce benefits unless it is laid out on structurally converging economies. Along with the views expressed in the European Commission White Paper, that the form will follow the 
function, we emphasize the importance of designing the proper institutions at European Union and Eurozone level, but also at national level (according to the specificities of each country), with taking into consideration the goal of advancing towards structural convergence. This would lead to real convergence (Buti and Turrini, 2015) and further integration will be possible.

A final conclusion that we depicted from the literature is that integration does not only lead to convergence to a certain extent (Karras, 1997), but also integration cannot advance beyond a certain point unless convergence advances too.

\section{References}

Abegaz, B. (2002). Structural Convergence in Manufacturing Industries between Leaders and Latecomers, Journal of Development Studies, 38(4), 69-99

Barrios, S., Barry, F. \& Strobl, E. (2002). FDI and Structural Convergence in the EU Periphery. Mimeo, University College Dublin.

Beck, K. (2014). Structural Similarity as a Determinant of Business Cycle Synchronization in the European Union: A Robust Analysis. Research in Economics and Business: Central and Eastern Europe, 5(2).

Berardino, Di, C., Mauro, G., Quaglione, D., \& Sarra, A. (2017). Structural change and the sustainability of regional convergence: Evidence from the Italian regions. Environment and Planning C: Politics and Space, 35(2), 289-311.

Branson, W. H., Guerrero, I., \& Gunter, B. G. (1998). Patterns of Development.

Brixiova, Z., M. Morgan \& A. Wörgötter (2009). Estonia and Euro Adoption: Small Country Challenges of Joining EMU, OECD Economics Department Working Papers, No. 728, OECD. Retrieved from http://dx.doi.org/10.1787/220860037027.

Brülhart, M. (1998). Economic geography, industry location and trade: the evidence. The World Economy, 21(6), 775-801.

Buti, M. \& Turrini, A. (2015). Three waves of convergence. Can Eurozone countries start growing together again?, VOX, CEPR's Policy Portal. Retreived from: http://voxeu.org, 17 April 2015.

Chenery, H.B. (1960). Patterns of Industrial Growth, American Economic Re-view, 50(4), 624-654.

Chenery H.B. (1975). The Structuralist Approach to Development Policy, American Economic Review, 65(2), 310-331.

Chenery H.B. (1979). Structural Change and Development Policy, Oxford Uni-versity Press, Oxford.

Chenery H.B., \& Taylor L. (1968), Development Patterns: Among Countries and Over Time, Review of Economics and Statistics, 50(4), 391-416.

Chenery, H. (1982). Industrialization and Growth, the Experience of Large Countries, World Bank Staff Working Papers, Number 539.

Chenery, H. B. \& Syrquin, M. (1975). Patterns of Development: 1950-1970, New York: Oxford University Press for the World Bank.

Chilian, M. N., Iordan, M., \& Pauna, C. B. (2016, December). Real and structural convergence in the Romanian counties in the pre-accession and post-accession periods. In ERSA conference papers (No. ersa16p320). European Regional Science Association.

Chong, C. Y., Habibullah, M. S., Baharumshah, A. Z., \& Midi, H. (2017). Structural Convergence Among ASEAN Economies. Advanced Science Letters, 23(9), 87478751.

Cincibuch, M. \& Vávra, D. (2000). Towards the EMU: A Need for Exchange Rate Flexibility?, Reihe Transformationsökonomie Transition Economics Series, July 2000, No 17, 
Institute for Advanced Studies Vienna, Retreived from:

http://irihs.ihs.ac.at/1268/1/te-17.pdf.

Crespo, N., \& Fontoura, M. P. (2010). Determinant factors of structural similarity at the regional level: evidence from Portugal. Applied Econometrics and International Development, 10 (1), 81-93.

Cuadrado-Roura, J. R., García-Greciano, B., \& Raymond, J. L. (1999). Regional convergence in productivity and productive structure: The Spanish case. International Regional

PICBE | 42 Science Review, 22(1), 35-53.

Dima, A. M. (Ed.). (2014). Handbook of Research on Trends in European Higher Education Convergence. IGI Global.

Dima, M.A. and Vasilache, S. (2016). Trends in the internationalization of European higher education in a convergence perspective. Management \& Marketing. Challenges for the Knowledge Society, 11(2), 449-457.

Dunkel, T. (2009). The Bologna process between structural convergence and institutional diversity. European journal of vocational training, 46(1), 174-195.

EEAG (2011). The EEAG Report on the European Economy, CESifo, Munich, Retreived from: http://blog.iese.edu/xvives/files/2011/09/Report-on-the-European-Economy2011.pdf

European Commission (2015). The European Higher Education Area in 2015: Bologna Process Implementation Report. Luxembourg: Publications Office of the European Union.

European Commission (2016). The 2016 Convergence Report: Assessment of Member States regarding the conditions for euro adoption, Brussels, 7 June 2016.

European Commission (2017). White Paper on the Future of Europe. Reflections and scenarios on the EU27 by 2025, Bruxelles, ISBN: 978-92-79-66241-6, doi: $10.2775 / 32364$.

Fagerberg, J. (2000). Technological progress, structural change and productivity growth: a comparative study. Structural Change and Economic Dynamics, 11, 393-411.

Fertő, I. (2016). Structural transformation in Central and Eastern European countries' agriculture: Convergence or Divergence?. ADVANCES IN ECONOMICS AND BUSINESS, 4(10), 547-552.

Frankel, J. A. \& Rose, A. K. (1997). Economic Structure and the Decision to Adopt a Common Currency. Stockholm University, Institute for International Economic Studies, Seminar Papers 611.

Garcia-Herrero, A. \& J. Ruiz (2005). How Much do Trade and Financial Linkages Matter for Business Cycle Synchronization?, Retreived from/: www.eco.uc3m.es/jruiz/TFSynchronization.pdf.

Guerrieri, G. \& S. Iammarino (2003). The Dynamics of Export Specialisation in the Regions of the Italian Mezzogiorno: Persistence and Change. SPRU Electronic Working Papers No. 105.

Gugler, K. \& M. Pfaffermayr (2004). Convergence in Structure and Productivity in European Manufacturing?. German Economic Review, 5, 61-79.

Höhenberger N. \& Schmiedeberg, C. (2008). Structural Convergence of European Countries, center for European. Governance and economic development research, discussion papers. No. 75, July. CeGE Discussion Paper, Retreived from: https://www.econstor.eu/handle/10419/32002

Imbs, J. și Wacziarg R. (2003). Stages of Diversification, American Economic Review, 93 $3(1), 63-86$. 
Jackson R.W., Hewings, G.J.D. \& Sonis, M. (1989), Decomposition Ap-proaches to the Identification of Change in Regional Economies, Economic Geography, 65(3), 216231.

Jackson R.W., Rogerson P., Plane D., \& Huallachain O. B.. (1990). A Causa-tive Matrix Approach to Interpreting Structural Change, Economic Systems Research, 2(3), 259269.

Ju, J., Lin, J.Y. \& Wang, Y. (2009). Endowment Structures, Industrial Dynamics, and Economic Growth. World Bank Policy Research Working Paper, No. 5055.

Juncker, J. C., Tusk, D., Dijsselbloem, J., Draghi, M.. \& Schulz, M. (2015). Completing Europe's economic and monetary union. Retrieved from: https://ec.europa.eu/commission/sites/beta-political/files/5-presidentsreport_en.pdf

Karras, G. (1997). Economic Integration and Convergence: Lessons from Asia, Europe and Latin America. Journal of Economic Integration, 12 (4), 419-432.

Knill, C. (2005). Introduction: Cross-national policy convergence: concepts, approaches and explanatory factors. Journal of European public policy, 12(5), 764-774.

Krugman, P. (1993). Lessons of Massachusetts for EMU. In Torres, F., Giavazzi, F. (Eds.). Adjustment and Growth in the European Monetary Union (pp. 241-261). Cambridge University Press.

Kuznets, S. (1956). Quantitative Aspects of the Economic Growth of Nations: I. Levels and Variability of Rates of Growth. Economic Development and Cultural Change. 5 (1), 594.

Landesmann, M. (2000). Structural change in the Transition Economies 1989-1999, Economic Survey of Europe, 2.

Longhi, C. \& A. Musolesi (2007). European cities in the process of economic integration: towards structural change, Annuals of Regional Science, 41, 333-351.

Marelli, E., Signorelli, M. \& Tyrowicz, J. (2012). Crises and Joint Employment-Productivity Dynamics: A Comparative Perspective for European Countries., Comparative Economic Studies, 54(2), 361-394.

Melihovs A. \& Kasjanovs I. (2011). The Convergence Processes in Europe and Latvia. Latvijas Banka, Discussion Papers 2011/01.

Midelfart-Knarvik, K., H.G. Overman, S.J. Redding \& A.J. Venables (2000). The Location of European industry, European Commission (Eds.). European integration and the functioning of product market, Brussels, 213-270.

Miron, D., Dima, A. \& Paun, C. (2009). A model for assessing Romania's real convergence based on distances and clusters methods. Munich Personala RePEc Archive MPRA, No. 31410, pp. 1-18

Mongelli, F. P., Reinhold, E., \& Papadopoulos, G. (2016). What's so special about specialization in the euro area? Early evidence of changing economic structures. Occasional Paper Series 168, European Central Bank.

Paci, R., \& Pigliaru, F. (1997). Structural change and convergence: an Italian regional perspective. Structural Change and Economic Dynamics, 8(3), 297-318.

Palan, N., \& Schmiedeberg, C. (2010). Structural convergence of European countries. Structural Change and Economic Dynamics, 21(2), 85-100.

Pigliaru, F. (2003). Detecting Technological Catch-Up in Economic Convergence. Metroeconomica, 54(2-3), 161-178.

Prados de la Escosura, L. P. (2007). European patterns of development in historical perspective. Scandinavian Economic History Review, 55(3), 187-221.

Qiu, J. (2014). Crisis in the Eurozone: Analyzing the EMU under the Framework of Optimum Currency Area Theories (Doctoral dissertation). 
Sassi, M. (2007, April). Structural change and economic convergence across the Eu-15 regions: can the agricultural sector play a role. In Agricultural Economics Society s 81st Annual Conference, University of Reading, UK, 2nd to 4th.

Scharpf, F. W. (2016). Forced Structural Convergence in the Eurozone-Or a Differentiated European Monetary Community.

Snaith, H. (2014). Narratives of optimum currency area theory and eurozone governance. New Political Economy, 19(2), 183-200.

Srinivasan, T. N., \& M. G. Quibria (2009). Technological Progress, Factor Endowments and Structural Change: A Note. The Bangladesh Development Studies, 32(4), 95-105. Retrieved from http://www.bids.org.bd/.

Teichler, U. (2012). International student mobility in Europe in the context of the Bologna Process. Journal of International Education and Leadership, 2(1), 1-13 Retrieved from http://www.jielusa.org/.

Wacziarg, R. (2004). Structural convergence. Manuscript, Stanford University. Retrieved from http://cddrl.fsi.stanford.edu/. 